\title{
Independent of DAZL-T54A variant and AZF microdeletion in a sample of Egyptian patients with idiopathic non-obstructed azoospermia
}

This article was published in the following Dove Press journal: The Application of Clinical Genetics

\author{
Mohammed M El Shafae' \\ Jehan H Sabry' \\ Eman G Behiry' \\ Hanan H Sabry ${ }^{2}$ \\ Mona A Salim' \\ Alaaeldin G Fayez ${ }^{3}$ \\ 'Department of Clinical and \\ Chemical Pathology, Benha Faculty \\ of Medicine, Benha University, Benha, \\ Egypt; ${ }^{2}$ Department of Dermatology, \\ Venereology and Andrology, Benha \\ Faculty of Medicine, Benha University, \\ Benha, Egypt; ${ }^{3}$ Department of \\ Molecular Genetics and Enzymology, \\ Human Genetics and Genome \\ Research Division, National Research \\ Centre, Cairo, Egypt
}

Background: The microdeletion events that occur in the $\mathrm{Y}$ chromosome-azoospermia factor $(A Z F)$ region may lead to dyszoospermia. Also, the deleted azoospermia $(D A Z)$ gene on AZFc and autosomal deleted azoospermia like gene $(D A Z L)$ are suggested to represent impairment, so it is interesting to determine the independency pattern of the $A Z F$ region and $D A Z L$ gene in azoospermic patients.

Aim: To study the molecular characterization of $A Z F C$ and $D A Z L$ in 64 idiopathic non-obstructed azoospermia patients and 30 sexually reproductive men.

Methods: SYBR Green I (Q-PCR) and AZF-STS analysis was used for DAZ gene, and SNVPCR and confirmative Sanger sequencing for $D A Z \mathrm{~L}$ gene.

Results: The present study observed that $15.6 \%$ had $A Z F$ c microdeletion, out of which $10 \%$ had $D A Z 1 / 2$ deletion, and no $T 54 A$ variant in the $D A Z L$ gene was found.

Conclusion: In the current work, the novelty is that spermatogenic impairment phenotype, present with $A Z F C$ microdeletions, is independent of the $T 54 A$ variant in the $D A Z L$ gene, and $A Z F C$ microdeletions could be a causative agent in spermatogenic impairment.

Keywords: male infertility, azoospermia, AZF, DAZL, deletion

\section{Introduction}

Worldwide, infertility is estimated to affect about 186 million people (from 8 to $12 \%$ of reproductive-aged couples), and more than half of all cases of global childlessness are due to male infertility. ${ }^{1,2}$ It is estimated that, in about $30 \%$ of cases, male infertility is due to a genetic disorder such as aneuploidy, structural chromosomal abnormalities, DNA damage, and gene mutations, including a variety of newly discovered genes. ${ }^{3}$

There has been an intensive search for genetic causes of male infertility, of which spermatogenic failure is the most common form. Screening with markers on the long arm of the human $Y$ chromosome has detected Yq microdeletions in 5-15\% of males with spermatogenic failure. Among cases with Yq microdeletions, deletion involving the azoospermia factor (AZF) region in the $\mathrm{Y}$ chromosome has been discovered to be a frequent genetic cause associated with male infertility. ${ }^{4}$ The AZFc region is particularly interesting, as approximately $80 \%$ of AZF microdeletions occur in this region, and most of them result in entire DAZ (deleted in azoospermia) gene deletion. ${ }^{5}$ The DAZ gene has four copies and most commonly encodes an RNA-binding protein exclusively in testicular tissue. ${ }^{6,7}$ Studies have demonstrated that the DAZ gene plays an important role in spermatogenesis. ${ }^{8,9}$ Although most deletions involve a deletion of all four DAZ genes, an absence of only two of the DAZ genes is also associated with impaired spermatogenesis. ${ }^{10}$ Detailed analysis of the AZFc region using new molecular
Correspondence: Jehan H Sabry Department of Clinical and Chemical Pathology, Benha Faculty of Medicine, Benha University, Benha 13015, Egypt Tel +202 1097372340 Email jehanrayan@yahoo.com 
non-repeating sequence-tagged site (STS) markers has confirmed the existence of three such microdeletions, namely, gr/gr, b1/b3, and b2/b3. ${ }^{11,12}$ The most prevalent partial deletion, the gr/gr deletion, is caused by recombination between amplicons $\mathrm{g}$ and $\mathrm{r}(\mathrm{g} 1, \mathrm{r} 1$, and/or $\mathrm{r} 2$, with their respective homologous amplicons g2, r3, and/or r4). ${ }^{13,14}$

The $D A Z$ gene has an autosomal homolog, $D A Z L$ (DAZlike), on chromosome $3 \mathrm{p} 24$. It is highly homologous to the $D A Z$ gene, with $83 \%$ similarity in the coding region of the cDNA. Both genes encode RNA-binding proteins. It is believed to play a role in spermatogenesis. ${ }^{15-17}$

$D A Z L$ gene encoding RNA binding protein is specifically expressed in germ cells of male and female and targets Tpx-1. ${ }^{18}$ Tex 19.1, Sycp3, and DDX4 transcripts in its 3'UTR region. ${ }^{19}$ In Taiwanese men, but not in Caucasians, who ranged from hypospermatogenesis and maturation arrest to Sertoli cell-only syndrome, Teng et $\mathrm{al}^{20}$ identified a c.386G $>\mathrm{A}$ transition in exon 3 of the DAZL gene which led to p.T54A substitution in the RNA recognition motif domain in $7.39 \%$ of patients. p.T54A was not detected in populations from Germany, Italy, Japan, Northern China, or Western India. Because that p.T54A variant of the DAZL gene has not been tested on infertile Egyptian men, and DAZ copy number variations is considered a main key in spermatogenesis, it is reasonable to investigate conjoining DAZ and DAZL genotyping in male infertility.

We aimed to study microdeletions in the AZF region and copy number variations in the DAZ region and also study p.T54A variant of DAZL gene in idiopathic non-obstructed azoospermic (NOA) Egyptian patients.

\section{Subjects and methods}

This study was approved by the Medical Ethical Committee of Benha Faculty of Medicine, Benha University, and the Medical Ethical Committee of the National Research Centre (Egypt) according to the "World Medical Association Declaration of Helsinki." Written informed consent was signed by all participants.

This case-controlled study was conducted on 64 NOA Egyptian patients (with age ranging from 20-47) years who were examined in the Department of Dermatology and Andrology, Benha Faculty of Medicine, Benha University, and National Research Centre, between January and December 2016.

Patients with spermatogenic impairment due to causes, such as obstruction of the vas deferens, history of and/or active orchitis, hyperprolactinemia, hypogonadotropic hypogonadism, previous chemo- or radiotherapy, or a history of unilateral and bilateral cryptorchidism and varicocele were excluded. The patients were evaluated for karyotype abnormalities, and those showing chromosomal abnormalities were excluded.

All patients underwent comprehensive surveillance, including a detailed history taking, physical examination, at least two semen analyses, endocrinology profiles testing (LH, FSH, prolactin [PRL], and testosterone). Semen samples were collected by masturbation after 3-5 days of abstinence. The diagnosis of azoospermia was established by pellet analysis after semen centrifugation that was repeated at least twice to confirm azoospermia. In patients with highly suspected non-obstructive azoospermia, bilateral testicular fine needle aspiration cytological analysis were done. Non-obstructive azoospermia was defined as: 1) spermatogenic defects in the testicular cytology (such as hypospermatogenesis, maturation arrest, and Sertoli cell-only syndrome) or 2) elevated serum FSH level, total testicular volume less than $30 \mathrm{ml}$. Semen analysis was performed according to the standard methods outlined by the World Health Organization. ${ }^{21}$

Thirty age-matched proven fertile men with a normal semen analysis and karyotype were recruited as controls. The control subjects were husbands of women who received regular prenatal care at the University hospital. All control individuals had fathered at least one child during the last 3 years and never had any sexual abnormality.

\section{Molecular investigations I-a-AZF-STS analysis}

Blood samples were collected using $\mathrm{Na}_{2}$ EDTA as an anticoagulant inside vacutainer sterile tubes. DNA was isolated from peripheral blood leukocytes followed by $A Z F-S T S$ analysis using six $A Z F C$-specific STSs (sY84, sY86, sY127, sY134, sY245, and sY255) according to the European Academy of Andrology and the European Molecular Genetics Quality Network (EAA/EMQN) guidelines. ${ }^{22}$ This guideline indicated that the use of these six STS loci are most relevant to the reported Y-chromosome microdeletions cases. An STS was considered absent only after at least two amplification failures in the presence of successful amplification of control (SRY-sY14). AZF-STS microdeletion screening was done by two multiplex polymerase chain reactions (PCRs), each covering the three AZF regions.

\section{I-b-Copy number estimation of DAZ genes using SYBR Green I (Q-PCR)}

We estimated copy numbers of DAZ genes using KAPA SYBR FAST qPCR Master mix (2X) (Code; KM4100, Kapa Biosys- 
tem, Boston, MA, USA), the primer sequences are shown in Table 1. Four copied STS sY587 located in intron 10 of the DAZ gene were chosen for quantification. All runs were carried out in duplicate, with the calibrator sample containing the four $D A Z$ genes and a reference sample. qPCR assay was performed using 40 cycles at denaturation $95^{\circ} \mathrm{C}$ for $8 \mathrm{~s}$, annealing at $58^{\circ} \mathrm{C}$ for $20 \mathrm{~s}$, extension at $72^{\circ} \mathrm{C}$ for $3 \mathrm{~s}$, followed by a dissociation step from $40^{\circ} \mathrm{C}$ to $85^{\circ} \mathrm{C}$ according to the Roch Light Cycler $480 \mathrm{II}$ instrument guideline. The data were analyzed using the comparative $\mathrm{Ct}(\Delta \Delta \mathrm{Ct})$ relative quantitation assay method. ${ }^{23}$

\section{I-c-Characterization of partial DAZ deletion using SNV-PCR}

To determine which type of $D A Z$ gene is deleted, we carried out single-nucleotide variants (SNVs) PCR analysis using sY587/DraI PCR-restriction fragment length polymorphism (RFLP). The digested products (Table 2) were run on a $3 \%$ agarose gel containing ethidium bromide and visualized by BioRad Gel doc instrument.

Table I DAZ gene fragments after Dral digestion

\begin{tabular}{llll}
\hline STS & $\begin{array}{l}\text { Restriction } \\
\text { enzyme }\end{array}$ & DAZ genes & $\begin{array}{l}\text { Length of } \\
\text { digested } \\
\text { fragments } \\
\text { (bps) }\end{array}$ \\
\hline sY587 & Dral & DAZ3/DAZ4 & 195 \\
& & DAZI/DAZ2 & $122 / 77$ \\
& & DAZI/DAZ2/DAZ3/DAZ4 & $49 / 26$ \\
\hline
\end{tabular}

Abbreviations: $D A Z$, deleted azoospermia; STS, sequence-tagged site; bps, base pairs.

Table 2 The designed primers sequence for exon 3 of the $D A Z L$ gene and AZF spanning primers

\begin{tabular}{ll}
\hline Name & $\mathbf{5 - - - - - 3}$ \\
\hline DAZL-D Forward & AAG AGC TAC TGG TCA TTT GGG G \\
DAZL-D Reverse & CTC TAT ACG TGG CTA GAG TTC AGA \\
sY587 Forward & TGG TTA ATA AAG GGA AGG TGT TTT \\
sY587 Reverse & TCT CCA GGA CAG GAA AAT CC \\
sYI4 Forward & GAA TAT TCC CGC TCT CCG GA \\
sYI4 Reverse & GCT GGT GCT CCA TTC TTG AG \\
sY86 Forward & GTG ACA CAC AGA CTA TGC TTC \\
sY86 Reverse & ACA CAC AGA GGG ACA ACC CT \\
sYI27 Forward & GGC TCA CAA ACG AAA AGA AA \\
sYI27 Reverse & CTG CAG GCA GTA ATA AGG GA \\
sY254 Forward & GGG TGT TAC CAG AAG GCA AA \\
sY254 Reverse & GAA CCG TAT CTA CCA AAG CAG C \\
sY84 Forward & AGA AGG GTC TGA AAG CAG GT \\
sY84 Reverse & GCC TAC TAC CTG GAG GCT TC \\
sYI34 Forward & GTC TGC CTC ACC ATA AAA CG \\
sYI34 Reverse & ACC ACT GCC AAA ACT TTC AA \\
sY255 Forward & GTT ACA GGA TTC GGC GTG AT \\
sY255 Reverse & CTC GTC ATG TGC AGC CAC \\
\hline
\end{tabular}

Abbreviations: $D A Z L$, deleted azoospermia like gene; AZF, azoospermia factor.

\section{II-a-Genotyping of T54A variant in DAZL gene by PCR-RFLP}

Genotyping of T54A variant in DAZL gene was performed in $25 \mu \mathrm{L}$ final volume reaction mix, containing up to $1 \mu \mathrm{g}$ of genomic DNA. We designed specific PCR primers (Table 1) covering exon 3 (based on GRCh37.p13 Primary Assembly) using NCBI Primer-BLAST tool. ${ }^{24}$ The amplified product was 262 bps in length. Amplicons were digested using the restriction enzyme AluI (New England Biolabs, Ipswich, MA, USA). The restriction fragments were run on a $4 \%$ agarose gel. The normal allele is cut into three restriction fragments of 142,115 , and $5 \mathrm{bps}$, whereas the polymorphism $\mathrm{A} \rightarrow \mathrm{G}$ creates an $A l u \mathrm{I}$ restriction site ( $A G C T$ ) giving four fragments of $129,115,13$, and $5 \mathrm{bps}$.

\section{II-b-Confirmative Sanger sequencing for exon 3 of DAZL gene}

To confirm the restriction enzyme AluI results, amplicon of exon 3 was followed by direct Sanger Sequencing using the BigDye Terminator Cycle Sequencing kit (Perkin-Elmer Inc., Waltham, MA, USA) on the ABI3730XL sequencer in Macrogen Inc. (South Korea) (http://dna.macrogen.com).

\section{Statistical methods}

The obtained data were tabulated and analyzed using SPSS version 16 software (SPSS Inc., Chicago, IL, USA). Categorical data were presented as numbers and percentages. A $P$-value $<0.05$ was considered statistically significant and $<0.01$ was considered highly statistically significant. Chi square test $\left(\chi^{2}\right)$, odds ratios (ORs), and the corresponding $95 \%$ CI were calculated when applicable.

\section{Results}

The mean age of subjects was $31.4 \pm 6.1$ years (range $=20-47$ years). Both studied groups showed normal hormonal mean levels (follicle stimulating hormone [FSH], luteinizing hormone [LH], and testosterone) with a non-significant statistical difference. qPCR showed that $\triangle \Delta \mathrm{Ct}$ normal references for the four $D A Z$ copies (b2/b4) is 4 (3.6-4.8), and for the two copies $(g r / g r, b 1 / b 3$, and $g 1 / g 3)$ is $2(1.6-2.2)$. DAZ-copy number variant $(\mathrm{CNV})$ by SNV-PCR was done in cases that showed reducing $D A Z$ gene numbers by real-time PCR only. PCRRFLP showed that, among 60 azoospermic cases, six cases had $D A Z 1 / 2$ deletion $(6 / 60,10 \%)$ (Figure 1). None of the exon 3 PCR products of 64 patients and 30 controls showed a mutant digestion pattern in DAZL (Figure 2). The obtained $D A Z L$ digestion patterns were confirmed by bidirectional Sanger sequencing, which showed no clear $A \rightarrow G$ transition 


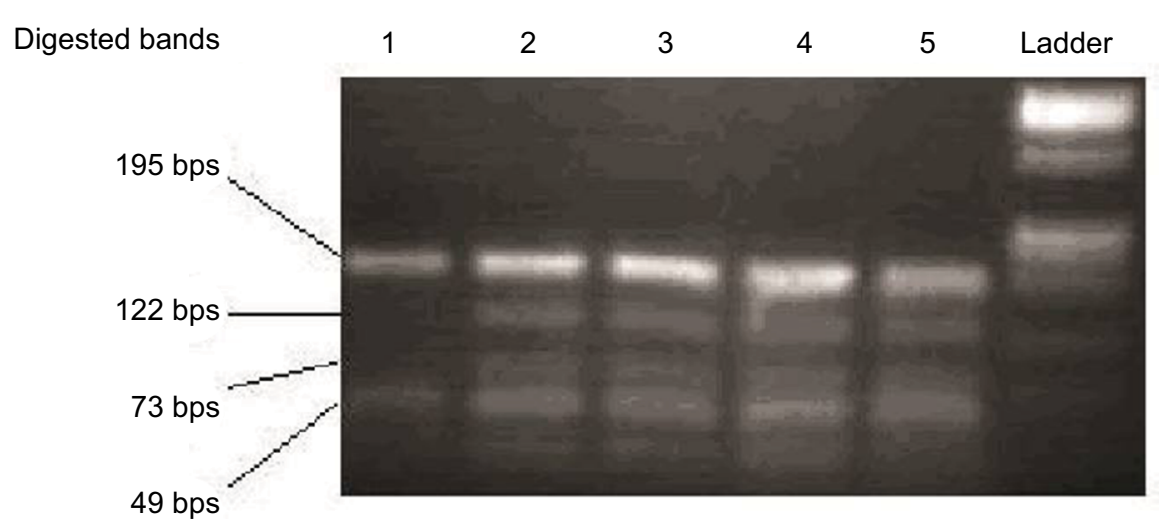

Figure I Agarose gel electrophoresis for restriction enzyme assay by Dral showed that case no I had an absent I 22 bps fragment, indicating that DAZI/2 were deleted. Abbreviation: bps, base pairs.

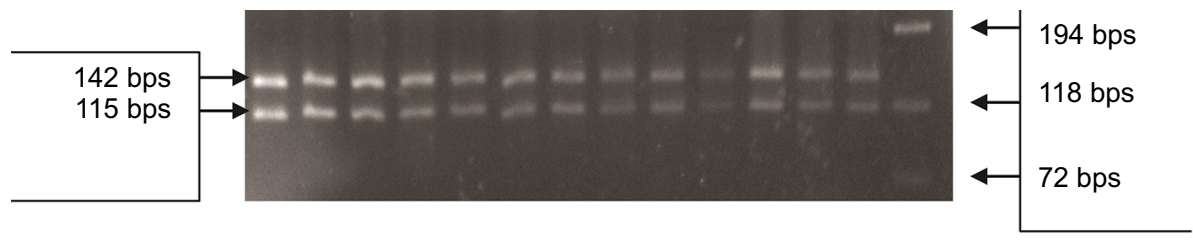

Figure 2 PCR-RFLP in patients for P.T54A variant in the DAZL gene. The 262 bps PCR product was digested with Alu I and resolved on $4 \%$ agarose gel. All lanes from I to I3 show a normal digestion pattern with the 142 and II 5 bps bands, where the 5 bps band was invisible. The phi XI74 DNA-Hae III ladder was used to size the digested bands. Abbreviations: PCR, polymerase chain reaction; DAZL, deleted azoospermia like gene; bps, base pairs; RFLP, restriction fragment length polymorphism.

(Figure 3). All normospermic fertile men (control group) had no detected AZF deletions using the same technique. The full results are shown in Tables 3 and 4.

\section{Discussion and conclusion}

Infertility is a disease that affects about one in six couples at reproductive age. Approximately half of the infertile cases are due to male factors, including abnormal semen parameters and azoospermia. ${ }^{21,25}$

The frequency and type of Y chromosome microdeletions varied according to ethnic, regional differences, selection criteria for patient samples, or methodological differences. ${ }^{26}$ Reports on the presence of Y chromosome microdeletions in infertile men range from $0.23 \%$ to $34.5 \%$, regardless of the number of STSs used, this wide range may be attributed to population/ethnic variances, selection criteria of the patients, methodological aspects, and environmental factors. ${ }^{27-29}$ Our results reported $A Z F-Y$ chromosome microdeletion in $15.6 \%$, where $4.7 \%$ presented in sY245 and 255 together, $1.6 \%$ presented in sY84 and 134 together, and 10\% (6/60) presented in $D A Z 1 / 2$ deletion.

To our knowledge, there are few studies which determined copy number variation of $D A Z$ genes by quantitative method such as real-time PCR technique. Also, T54A variant in multiple populations has long been investigated. However, no studies have specifically examined this variant in infertile men in an Egyptian population. Our study investigated the DAZ copy number variations using relative quantitative realtime PCR followed by SNV-PCR to analyze the variations of DAZ genes in those patients and investigated the T54A variant in exon 3 of DAZL gene using RFLP-PCR.

Shimizu et al ${ }^{30}$ proposed that approximately $10 \%$ of non-obstructive azoospermia patients are positive for $\mathrm{Y}$ chromosome $A Z F$ microdeletion. Liu et $\mathrm{al}^{31}$ showed that infertile non-obstructive azoospermia and severe oligospermia patients had an increased tendency to $A Z F c$ partial deletions (7.40\%) and $A Z F c$ deletions (4.14\%). Others studies showed that, in the Caucasian population, $15 \%$ of idiopathic azoospermia cases had deletion of either four $D A Z$ genes or $D A Z 1 / D A Z 2$ in the $A Z F c$ region, and $8.8 \%$ of Chinese azoospermic patients had complete deletion of $D A Z$ genes, and $D A Z 1 / D A Z 2$ deletion was confirmed in $8.3 \%$ of azoospermic patients. ${ }^{32-34}$ Our results showed a frequency of $10 \%$ of studied NOA had $D A Z 1 / 2$ deletion and $4.7 \%$ had complete $A Z F C$ deletion, whereas other studies could not confirm the relationship between $A Z F$ microdeletions and male infertility. 35,36

A number of previous studies pointed that the $g r / g r$ deletion and the $g 1 / g 2$, which remove $D A Z$ copies 1 and 2 , represented a risk factor for spermatogenic damage. In 

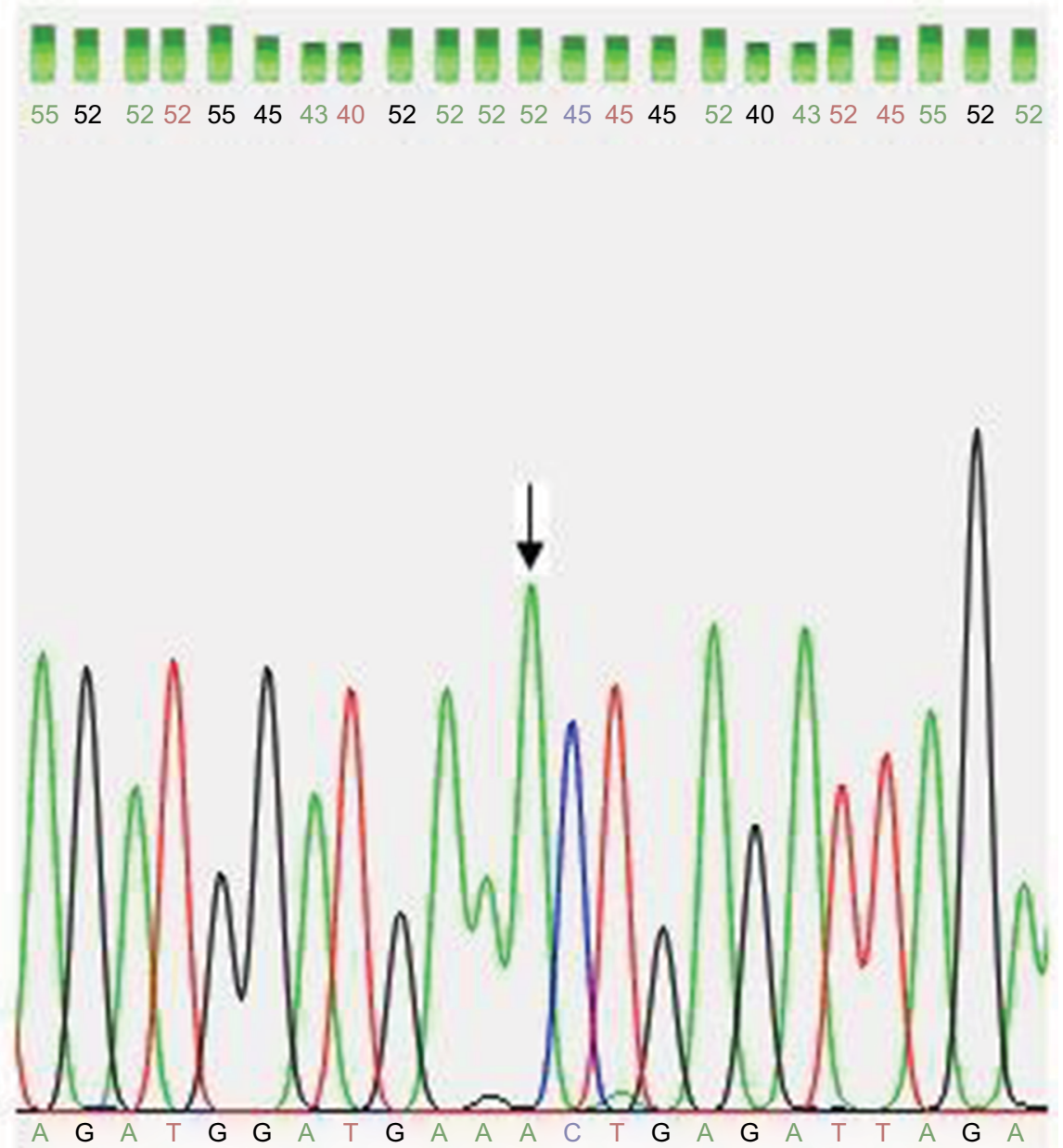

Figure 3 Partial DNA sequence chromatogram for exon 3 of the DAZL gene shows normal A allele (arrow). Abbreviation: DAZL, deleted azoospermia like gene.

Table 3 Chi-square analysis for whole AZF aberrations including DAZ-CNV

\begin{tabular}{|c|c|c|c|c|c|}
\hline Parameters & $\mathbf{n}$ & $\begin{array}{l}\text { With } \\
\text { del }\end{array}$ & $\begin{array}{l}\text { Percentage } \\
\text { (\%) }\end{array}$ & $\chi^{2 \S}$ & $P$-value* \\
\hline AZFa del & 64 & 0 & 0 & & \\
\hline AZFb del & 64 & 0 & 0 & & \\
\hline AZFc (sY254+255) del & 64 & 3 & 4.7 & 1.00 & 0.317 \\
\hline Partial AZFa+b (sY84+I34) & 64 & 1 & 1.6 & & \\
\hline$D A Z I / 2$ del & 60 & 6 & 10 & & \\
\hline - sY254+255 vs DAZI/2 & & & & 1.00 & 0.317 \\
\hline - $A Z F a, b$ and $c$ vs DAZI/2 & & & & 0.40 & 0.527 \\
\hline DAZ3/4 del & 60 & 0 & 0 & & \\
\hline$D A Z I / 2 / 3 / 4 \mathrm{del}$ & 60 & 0 & 0 & & \\
\hline Total AZF & 64 & 10 & 15.6 & & \\
\hline
\end{tabular}

Notes: ${ }^{\S}$ Chi-square test analysis. *Values for $P \leq 0.05$ were considered statistically significant at confidence level $95 \%$.

Abbreviations: AZF, azoospermia factor; DAZ, deleted azoospermia; CNV, copy number variant; del, deletion.

contrast, the $b 2 / b 3, g r / g r$, and $g 1 / g 3$ deletions, which remove $D A Z$ copies 3 and 4 , seemed to have no or little effect on fertility. ${ }^{37}$ In our results, no $D A Z 3 / 4$ deletion was detected.
Table 4 Chi-square analysis for each AZF and STS microdeletion

\begin{tabular}{llllll}
\hline Parameters & n & $\begin{array}{l}\text { With } \\
\text { del }\end{array}$ & $\begin{array}{l}\text { Percentage } \\
\text { (\%) }\end{array}$ & $\chi^{2 \S}$ & P-value* \\
\hline AZF microdeletions & & & & & \\
AZFa microdeletion & 64 & $\mathrm{I}$ & 1.6 & 11.64 & 0.003 \\
AZFb microdeletion & 64 & $\mathrm{I}$ & 1.6 & & \\
AZFc microdeletion & 64 & 9 & 14.1 & & \\
STS microdeletions & & & & & \\
sY84 & 64 & $\mathrm{I}$ & 1.6 & 2.00 & 0.572 \\
sY134 & 64 & $\mathrm{I}$ & 1.6 & & \\
sY254 & 64 & 3 & 4.7 & & \\
sY255 & 64 & 3 & 4.7 & & \\
\hline
\end{tabular}

Notes: ${ }^{\S} \mathrm{Chi}$-square test analysis. *Values for $P \leq 0.05$ were considered statistically significant at confidence level $95 \%$.

Abbreviations: AZF, azoospermia factor; STS, sequence-tagged site; del, deletion.

According to our knowledge, the Egyptian population was not tested for p.T54A variant, so the allele frequency for this variant in those populations is still unknown, and this is the first report about the T54A variant in a non-Taiwan Chinese population. 
Stratified analysis was performed by Zhang et al ${ }^{38}$ via meta-analysis of 13 case-control studies, including 2556 cases and 1997 controls, showed a strong association between p.T54A polymorphism and male infertility in Asians.

Tüttelmann et al ${ }^{39}$ reported, through a meta analysis study, that the p.T54A mutation was never found in non-Chinese populations and seems to be a factor associated with male infertility only in Taiwan.

Regarding the fact that the p.T54A variant of $D A Z L$ gene has not been studied in Egyptian infertile men, yet, we screened $\mathrm{A}$ and $\mathrm{G}$ alleles for $\mathrm{A} 360 \mathrm{G}$ variant of the $D A Z L$ gene using PCR-RFLP in 170 alleles of Egyptian infertile patients and 100 alleles of controls in order to study the allelic frequency of this variant in a sample of the Egyptian population. We did not find $\mathrm{G}$ allele in the patients or in the controls. Additional Direct Sanger sequencing for three samples with forward primer also showed A allele only.

Bartoloni et $\mathrm{al}^{40}$ described that sequencing for $A>G$ transition variant with the reverse primer was better from the forward one, because the forward primer led to a background which looked like the $A>G$ transition that was absent in sequences from the reverse primer. However, our results showed that sequencing $A>G$ transition variant using the forward primer was clear, without a noisy background (Figure 2).

Chen et $\mathrm{a}^{41}$ reported that partial $A Z F C$ deletions are independent of the variations in $D A Z L$. In our results, no coexistence pattern was found between the $T 54 \mathrm{~A}$ variant of $D A Z L$ gene and $A Z F$ defect in spermatogenic impairment in men with azoospermia.

Y chromosome studies could serve as a predictive factor in probability of sperm retrieval. So, the Y chromosome studies are important. Also, AZF microdeletion may be passed onto the next male generation; hence, it is important to screen specific DNA sequences on the $\mathrm{Y}$ chromosome before ICSI. Liu et al ${ }^{31}$ pointed out that detection of Y chromosome microdeletions is of great use for guiding clinical diagnosis, selecting treatment schemes, and reducing the incidence of this genetic disease .

We can conclude that 1) our study provides further evidence that partial deletions of the $A Z F C$ region, especially $D A Z 1 / 2$ deletion, are a risk factor for spermatogenesis impairment rather than $D A Z 3 / 4$ deletion, and this agrees with what was reported by Fayez et al; ${ }^{42} 2$ ) the spermatogenic impairment phenotype of $A Z F$ microdeletions is independent of the $T 54 A$ variant in the $D A Z L$ gene; and 3) the $p . T 54 A$ variant may be a founder variant for the Taiwanese population or incorrect result.
Therefore, we recommend evaluating the p.T54A variant in other populations to stand on the assumption that this variant is of doubtful existence. Also, because of different potential genetic factors contributing to the spermatogenic phenotype among populations of different ethnic origins, further genetic studies are required in more populations.

The novelty of the current study is independence of the spermatogenic impairment phenotype of $A Z F$ microdeletions and $T 54 A$ variant in the $D A Z L$ gene, also the absence of the $T 54 A$ variant in a sample of Egyptian infertile patients.

There were several limitations to this study: 1) only patients with NOA were examined; 2) the prevalence of these genetic factors used in our study is still unknown in the Egyptian population; and 3) no familial members were included to follow the $A Z F$ microdeletion.

\section{Acknowledgments}

The authors are very grateful to patients and controls for their participation and cooperation during this study. Financial funding of this paper was provided by the authors only.

\section{Disclosure}

All authors report no conflicts of interest in this work.

\section{References}

1. Inhorn, MC, Patrizio P. Infertility around the globe: new thinking on gender, reproductive technologies and global movements in the $21 \mathrm{st}$ century. Hum Reprod Update. 2015;21(4):411-426.

2. Ombelet W, Cooke I, Dyer S, Serour G, Devroey P. Infertility and the provision of infertility medical services in developing countries. Hum Reprod Update. 2008;14(6):605-621.

3. Vogt PH. Molecular genetic of human male infertility: from genes to new therapeutic perspectives. Curr Pharm Des. 2004;10(5):471-500.

4. Vogt PH, Edelmann A, Kirsch S, et al. Human Y chromosome azoospermia factors (AZF) mapped to different subregions in Yq11. Hum Mol Genet. 1996;5(7):933-43.

5. Simoni M, Bakker E, Krausz C. EAA/EMQN best practice guidelines for molecular diagnosis of Y-chromosomal microdeletions. State of the art 2004. Int J Androl. 2004;27(4):240-249.

6. Kim B, Lee Y, Kim Y, et al. Polymorphic expression of DAZ proteins in the human testis. Hum Reprod. 2009;24(6):1507-1515.

7. Writzl K, Zorn B, Peterlin B. Copy number of DAZ genes in infertile men. Fertil Steril. 2005;84(5):1522-1525.

8. Fernandes AT, Fernandes S, Gonçalves R, et al. DAZ gene copies: evidence of Y chromosome evolution. Mol Hum Reprod. 2006;12(8): 519-523

9. Reynolds N, Cooke HJ. Role of the DAZ genes in male fertility. Reprod Biomed Online. 2005;10(1):72-80.

10. Teng YN, Chang YP, Tseng JT, et al. A single-nucleotide polymorphism of the DAZL gene promoter confers susceptibility to spermatogenic failure in the Taiwanese Han. Hum Reprod. 2012;27(9):2857-2865.

11. Skaletsky H, Kuroda-Kawaguchi T, Minx PJ, et al. The male-specific region of the human $\mathrm{Y}$ chromosome is a mosaic of discrete sequence classes. Nature. 2003;423(6942):825-837. 
12. Repping S, Skaletsky H, Brown L, et al. Polymorphism for a 1.6-Mb deletion of the human $\mathrm{Y}$ chromosome persists through balance between recurrent mutation and haploid selection. Nat Genet. 2003;35(3): 247-251.

13. Kuroda-Kawaguchi T, Skaletsky H, Brown LG, et al. The AZFc region of the $\mathrm{Y}$ chromosome features massive palindromes and uniform recurrent deletions in infertile men. Nat Genet. 2001;29(3):279-286.

14. Hucklenbroich K, Gromoll J, Heinrich M, Hohoff C, Nieschlag E, Simoni M. Partial deletions in the AZFc region of the $\mathrm{Y}$ chromosome occur in men with impaired as well as normal spermatogenesis. Hum Reprod. 2005;20(1):191-197.

15. Saxena R, Brown LG, Hawkins T, et al. The DAZ gene cluster on the human Y chromosome arose from an autosomal gene that was transposed, repeatedly amplified and pruned. Nat Genet. 1996;14(3):292-299.

16. Shan Z, Hirschmann P, Seebacher T, et al. A SPGY copy homologous to the mouse gene Dazla and the Drosophila gene boule is autosomal and expressed only in the human male gonad. Hum Mol Genet. 1996;5(12):2005-2011.

17. Yen PH, Chai NN, Salido EC. The human autosomal gene DAZLA: testis specificity and a candidate for male infertility. Hum Mol Genet 1996;5(12):2013-2017.

18. Jiao X, Trifillis P, Kiledjian M. Identification of target messenger RNA substrates for the murine deleted in azoospermia-like RNA-binding protein. Biol Reprod. 2002;66(2):475-485.

19. Reynolds N, Collier B, Maratou K, et al. Dazl binds in vivo to specific transcripts and can regulate the pre-meiotic translation of Mvh in germ cells. Hum Mol Genet. 2005;14(24):3899-3909.

20. Teng YN, Lin YM, Sun HF, Hsu PY, Chung CL, Kuo PL. Association of DAZL haplotypes with spermatogenic failure in infertile men. Fertil Steril. 2006;86(1):129-135.

21. World Health Organization. Examination and Processing Human Semen. Geneva: World Health Organization; 2010:1-287.

22. Krausz C, Hoefsloot L, Simoni M, Tüttelmann F. EAA/EMQN best practice guidelines for molecular diagnosis of Y-chromosomal microdeletions: state-of-the-art 2013. Andrology. 2014;2(1):5-19.

23. Livak KJ, Schmittgen TD. Analysis of relative gene expression data using real-time quantitative PCR and the $2(-\Delta \Delta \mathrm{C}(\mathrm{T}))$ method. Methods 2001;25(4):402-408.

24. Ye J, Coulouris G, Zaretskaya I, Cutcutache I, Rozen S, Madden TL. Primer-BLAST: a tool to design target-specific primers for polymerase chain reaction. BMC Bioinformatics. 2012;13:134.

25. Sen S, Pasi AR, Dada R, Shamsi MB, Modi D. Y chromosome microdeletions in infertile men: prevalence, phenotypes and screening markers for the Indian population. J Assist Reprod Genet. 2013;30(3): 413-422.

26. Krausz C, Forti G, McElreavey K. The Y chromosome and male fertility and infertility. Int J Androl. 2003;26(2):70-75.
27. Foresta C, Moro E, Ferlin A. Y chromosome microdeletions and alterations of spermatogenesis. Endocr Rev. 2001;22(2):226-239.

28. Mierla D, Jardan D, Stoian V. Chromosomal abnormality in men with impaired spermatogenesis. Int J Fertil Steril. 2014;8(1):35-42.

29. Gonçalves C, Cunha M, Rocha E, et al. Y-chromosome microdeletions in nonobstructive azoospermia and severe oligozoospermia. Asian $J$ Androl. 2017;19(3):338-345.

30. Shimizu A, Ichikawa T, Suzuki N, et al. Microdeletions in the $\mathrm{Y}$ chromosome of patients with idiopathic azoospermia. Asian J Androl. 2002;4(2):111-115.

31. Liu XG, Hu HY, Guo YH, Sun YP. Correlation between Y chromosome microdeletion and male infertility. Genet Mol Res. 2016;15(2):1-6.

32. Yuan Y, Xiao CY, Zhang SZ, Zhang SX, Huang MK, Lin L. High risk genetic factor in Chinese patients with idiopathic male infertility; deletion of DAZ gene copy on Y chromosome. Chin Med J. 2004;117: 1092-1094.

33. Dada R, Gupta NP, Kucheria K. Yq microdeletions - azoospermia factor candidate genes and spermatogenic arrest. J Biomol Tech. 2004;15(3):176-183.

34. Fernandes S, Huellen K, Goncalves J, et al. High frequency of DAZ1/ DAZ2 gene deletions in patients with severe oligozoospermia. $\mathrm{Mol}$ Hum Reprod. 2002;8(3):286-298.

35. Ferlin A, Tessari A, Ganz F, et al. Association of partial AZFc region deletions with spermatogenic impairment and male infertility. $J$ Med Genet. 2005;42(3):209-213.

36. Visser L, Westerveld GH, Korver CM, et al. Y chromosome gr/gr deletions are a risk factor for low semen quality. Hum Reprod. 2009;24(10): 2667-2673.

37. Lu C, Zhang J, LiY, et al. The b2/b3 subdeletion shows higher risk of spermatogenic failure and higher frequency of complete AZFc deletion than the gr/gr subdeletion in a Chinese population. Hum Mol Genet. 2009;18(6): 1122-1130.

38. Zhang S, Tang Q, Wu W, et al. Association between DAZL polymorphisms and susceptibility to male infertility: systematic review with meta-analysis and trial sequential analysis. Sci Rep. 2014;4:4642.

39. Tüttelmann F, Rajpert-De Meyts E, Nieschlag E, Simoni M. Gene polymorphisms and male infertility-a meta-analysis and literature review. Reprod Biomed Online. 2007;15(6):643-658.

40. Bartoloni L, Cazzadore C, Ferlin A, Garolla A, Foresta C. Lack of the T54A polymorphism of the DAZL gene in infertile Italian patients. Mol Hum Reprod. 2004;10(8):613-615.

41. Chen P, Ma M, Li L, et al. Phenotypic expression of partial AZFc deletions is independent of the variations in DAZL and BOULE in a Han population. J Androl. 2010;31(2):163-168.

42. Fayez AG, El-Sayed AS, El-Desouky MA, et al. Molecular characterization of some genetic factors controlling spermatogenesis in Egyptian patients with male infertility. Int J Infertil Fetal Med. 2012;3(3):69-77.
The Application of Clinical Genetics

\section{Publish your work in this journal}

The Application of Clinical Genetics is an international, peer-reviewed open access journal that welcomes laboratory and clinical findings in the field of human genetics. Specific topics include: Population genetics; Functional genetics; Natural history of genetic disease; Management of genetic disease; Mechanisms of genetic disease; Counselling and ethical
Dovepress

issues; Animal models; Pharmacogenetics; Prenatal diagnosis; Dysmorphology. The manuscript management system is completely online and includes a very quick and fair peer-review system, which is all easy to use. Visit http://www.dovepress.com/testimonials.php to read real quotes from published authors. 